\title{
Human Resource Strategies as a Mediator between Leadership and Organizational Performance
}

\author{
Abdulrahman Alsughayir ${ }^{1}$ \\ ${ }^{1}$ Al-Imam Muhammad ibn Saud Islamic University-Riyadh, Kingdom of Saudi Arabia \\ Correspondence: Abdulrahman Alsughayir, Assistant Professor, Dean of Student Affairs, School of Economics \& \\ Administrative Science, Al Imam ibn Muhammad ibn Saud Islamic University, Riyadh, Sadui Arabia. Tel: \\ 9-665-559-94674. E-mail: aaalsughayir@yahoo.com
}

Received: December 16, 2013

Accepted: January 7, 2014

Online Published: February 24, 2014

doi:10.5539/ibr.v7n3p91

URL: http://dx.doi.org/10.5539/ibr.v7n3p91

\begin{abstract}
Leadership style is a kind of method that aims to realize organizational targets and affect all organizational activities. This quantitative study focused on various business domains in Saudi Arabia to examine how leadership styles are related to human resource strategies and organizational performance. The study adopted the self-administered survey methodology technique using a pre-validated pre-piloted questionnaire. Data were analyzed using Structural Equation Modelling. A total of 270 questionnaires were distributed with a response rate $92.9 \%$ based on a convenience method. Our survey found a direct positive relationship between leadership style and organizational performance and an indirect relationship between leadership style and human resource strategy as a mediator, while human resource strategies contribute positively and significantly to organizational performance. The findings are relevant for operating human resource management strategies and for developing a style of leadership. An enterprise can use this information to promote recognition and devotion among its employees based on a range of strategies, and then creates overall performance of the organization. Also, it is possible to use different leadership styles for different strategies. Consequently, this study has both theoretical and practical reference value.
\end{abstract}

Keywords: HRM strategy, leadership, performance, SEM, Saudi Arabia

\section{Introduction}

In today's competitive business world, organizations must adapt to meet their customers' needs. Organizations rely on their leaders to facilitate these changes and innovations. The degree to which an organization can meet its goals and objectives depends on its managers and the leadership styles of those managers. Managers who adopt appropriate leadership styles can impact productivity in a positive way. Studies have shown that an organization's performance is directly correlated to the leadership styles of its leaders.

There is a common belief that effective leadership positively influences organizational performance (Bass, 1997). In the United States context, Behling and McFillen (1996) confirmed a link between leadership and high performance by constructing a model of transformational/charismatic leadership in which a leader's behavior can inspire and empower his or her subordinates to exert high effort and commitment and be willing to take risks. Furthermore, for many organizations, success may result from leadership's wisdom, technical capability and innovation, excellent quality or a distinguished reputation, all of which are "human-related". Therefore, since 1980, a company's strategy for (HRM) has been an serious issue (Northouse, 2011).

\subsection{Aim of the Study}

While different studies have investigated the effect that HR strategy and leadership styles have on an organization's achievement, most such studies have been done in developed countries (Abbas, 2013). In fact, Nijssen, and Douglas (2004) questioned the validity of applying the findings from developed countries to smaller, less developed countries. It is not always possible to apply the research output from developed countries, such as the United States to less developed countries, such as Saudi Arabia (Abbas, 2013). Therefore, the aims of the present study were to investigate the effect of human resource strategies as a mediator between leadership style and organizational performance in the context of Saudi Arabia. Furthermore, to explore the effects of the interaction of both the human resource management strategy and leadership style towards the organizational 
performance.

\section{Literature Review}

\subsection{Leadership Style}

Mousavi et al. (2011) defined leadership as the process by which a subordinate is influenced by being inspired to achieve a target, the group cooperates, and the established mission is accomplished, with support from external groups. Fry (2003) defined leadership as the use of a strategy to inspire staff and enhance their potential for growth and development. Northouse (2011) described leadership as a process by which an individual influences a group to achieve a common goal.

According to Stogdill (1990), stated that a leadership style is a method and ability that aims to realize organizational targets and have an impact on all organizational functions. According to Fiedler (1969), a leadership style is a relationship by which someone influences a number of employees to work together in pursuit of a common goal. Four main new theories of leadership style have been presented: charismatic leadership, visionary leadership, transformational leadership, and transactional leadership (Northouse, 2011; Bass, 1997). These styles were adopted in the present study as the dimensions of leadership style which are discussed in more detail below.

\subsubsection{Transactional Leadership and Performance}

Transactional leadership is based on an organization's bureaucratic authority and legitimacy and emphasizes work levels, task-oriented goals, and assignments. The main focus is on completing tasks and employee compliance, while employee performance is influenced by organizational rewards and penalties. Robbins (2003) explained that transactional leaders guide or motivate their followers towards established targets by explaining roles and task requirements. Part of transactional leadership is an exchange process that leads to followers complying with their leader's request, but is unlikely to create commitment and enthusiasm for the task objective. Leaders focus on getting internal actors to carry those tasks that the organization needs to complete in task to reach its targets (Boehnke et al., 2003). A transactional leader's objectives are to ensure that internal actors clearly understand the path to goal attainment, to motivate actors, and to remove potential barriers in the system and to encourage employees to reach their targets (House \& Aditya, 1997). Guardia (2007) found transactional leadership to be the primary factor behind organizational success at the team and individual levels, and that there is a vital connection between such leadership behavior and individual and group performance factors.

\subsubsection{Transformational Leadership and Performance}

Transformational differs from transactional leadership in the way that individuals are motivated. The behavior of a transformational leader originates from his or her personal values and beliefs and will help motivate subordinates to achieve more than is expected of them (Long \& Thean, 2011). According to Burns (1978), transformational leadership is a process by which one or more individuals engage with others that helps leaders and followers increase each other's levels of motivation. According to Feinberg et al. (2005), transformational leaders promote and support cooperative decision making. Similarly, Gillespie and Mann (2004) argued that the leaders of an organization should encourage employees to grow and develop, offer emotional support, set high goals, and work to develop employees' capabilities. Gillespie and Mann (2004) also found that the ability of a transformational leader to communicate, and develop followers will help promote trusting relationships between the organization's members. Previous studies have indicated that transformational leadership is strongly correlated to organizational performance. This statement also expressed by Zhu et al. (2005) stated that transformational leadership has been positively linked to organizational performances and that the role of CEOs is vital to a firm's success.

\subsubsection{Charismatic Leadership}

Authentic leadership provides the basis for understanding why certain leaders are considered charismatic. Voon and Ayob (2011) argued that the influence of leadership originates from the nature and behavior of the leader. These factors may cause employees to perceive their leader as charismatic in the sense that the leader genuinely represents the group he or she leads and, moreover, that the leader's behavior reflects his or her own values and those of the group (Northouse, 2011).

\subsubsection{Visionary Leadership}

Visionary leaders innovate a strategic future vision, then communicate that vision by framing and using metaphors, modeling the vision through consistent action, and building commitment towards the vision (Voon \& Ayob, 2011; McShane \& Von Glinow, 2000). Scholars such as Zhu et al. (2005) have suggested that visionary 
leadership results in high levels of cohesion, trust, commitment, and motivation, and therefore performance in new organizational environments.

\subsection{Human Resource Management Strategy}

According to Dyer and Holder (1988), an organization's HRM strategy is a set of intra-organizational personnel management strategies. If such a strategy is effectively applied, this can help enterprises effectively use employees to achieve organizational targets. A number of scholars have attempted to delineate various HRM strategy types. These include those presented by Dyer and Holder (1988), namely, inducement strategy, investment strategy, and participation strategy, and the accumulation, facilitation, and utilization strategies. Northouse (2011) presented development strategy, reinforcement strategy, motivational strategy, and transfer strategy as dimensions of an HRM strategy.

\subsection{Organizational Performance}

According to Choi and Mueller (1992) argued the need for an enterprise to simultaneously consider financial and non-financial indices when evaluating performance. Certain non-financial indices are important for a company's long-term operation, including product quality and employee. Long and Thean (2011) claimed that organizations were most commonly measured using traditional financial performance factors such as return on investment, earning power, and, most commonly, sales revenue. Therefore, the present study has adopted the performance measurement methods that Ali et al. (2013) presented, such as financial performance, organizational effectiveness, and business performance, as dimensions of organizational performance.

\subsection{The Leadership Effect on the Organizational Performance}

There are a number of reasons for having a relationship between leadership and performance. The first of these is related to practice. Contemporary markets, which are intensive and dynamic, feature innovation-based competition, decreasing returns, rivalry between price and performance, and the creative destruction of existing competencies (Ali et al., 2013). Practitioners and scholars alike have suggested that effective leadership behaviors can help improve performance when organizations are faced with such new challenges (Judge \& Piccolo, 2004; Ali et al., 2013). It is also important to understand the effects of leadership on performance because researchers such as Zhu et al. (2005) have considered leadership to be a key driving force behind the management performance of any organization.

Effective leadership is considered an active way to develop management and improve organizational performance (Voon \& Ayob, 2011; Lado et al., 1992). Transactional leadership, for example, can help an organization to more efficiently achieve its objectives by connecting job performance to rewards and also by ensuring that employees have the necessary resources (Zhu et al., 2005).

Mehra et al. (2006) argued that organizations that are looking for efficient ways to outperform their competitors often focus on leadership. This leader-centered perspective has offered helpful insights into how leadership is related to team performance (Zhu et al., 2005). Some researchers (Keller, 1992; McGrath \& MacMillan, 2000; Purcell et al., 2004; Northouse, 2011) have explored the strategic role of leadership and how leadership paradigms and leadership behavior can be used to improve organizational performance. Previous research has generated expectations that leadership paradigms will directly affect customer satisfaction, financial performance, and staff satisfaction. In the extant leadership research, results tend of depend on the level of analysis. House and Aditya (1997) identified micro-level research with a focus on leaders in relation to their subordinates and immediate superiors, as well as macro-level research that has a closer focus on the overall organization and the organization's environment. According to Tarabishy et al. (2005) suggested that leaders, as well as their leadership styles, influence the subordinates and also influence organizational outcomes. This leads to our first hypothesis:

(H1): There is a positive relationship between leadership style and organizational performance.

\subsection{Leadership Style and HRM Strategy}

Successful leaders should eschew their own personal style and instead try to involve everyone in leadership, and combining leadership style with a HRM strategy will create suitable strategies over time (Guo, 2004). Accordingly, a HRM strategy that encourages and trains staff can encourage leaders to show their leadership style (Hewson, 1997). The HRM strategy should be the core of a leadership style (Qin, 1998).

With regard to management, leadership should not solely emphasize care for employees and efficiency. In an organizational environment, managers should choose a HRM strategy that is both proper and effective, and adopt leadership style that is suitable for leading organizational members toward the organization's targets (Qin, 1998). Accordingly, leaders combine communication, integration, and excitation to effectively implement the HRM 
strategy (Keller, 1992). Based on the above discussion, we have formulated the following hypothesis:

(H2): There is a significant positive relationship between leadership style and human resource management strategy.

\subsection{HRM Strategy and Organizational Performance}

The HR function has changed greatly in recent years, with HR professionals coming to be viewed more as business partners. The organization's HR strategy should have a similar orientation in order to ensure the organization's success and also its sustenance. For example, business leaders must continually evaluate their talent area in order to determine whether their organization has the appropriate expertise needed to achieve the company's business strategy. Integrating HR strategy into the company's business strategy forms the basis upon which the HR function can support and implement the company's strategic plan in order to achieve a competitive advantage. The most profitable organizations are the ones that align their HR and business strategies. If an HR strategy is to help improve the organization performance, it must be well-documented and integrated into the overall business strategy. It must include practices that implement the business strategy through the organization furthermore; it must be treated as part of the company's leadership group, which has the ability to influence the business (Judge \& Piccolo, 2004).

Riaz and Haider (2010) believed that effective HRM strategies (which includes attitude assessment, recruitment and selection, work design, performance evaluation, labor participative management plans, incentive compensation, performance rewards, information sharing, and complaint handling procedures) can contribute to organizational performance. The degree of HR alignment can help indicate whether the work of the HR function is adding value to the bottom line of the business. To align HR, successful organizations stop viewing HR as a department with a budget, personnel, and tasks, and they instead define it as an organization that has customers, resources, and services to deliver. The next step is to determine whether the "customers" are receiving the "services" they expect.

According Riaz and Haider (2010), innovative HRM strategies; such as training; careful selection; and incentive compensation, correlates positively with organizational performance. This led to H3:

(H3): There is a positive relationship between HRM strategy and the organizational performance.

\section{Methods}

Based on our literature review and the three hypotheses presented above, we have constructed our research framework, as shown in Figure 1.

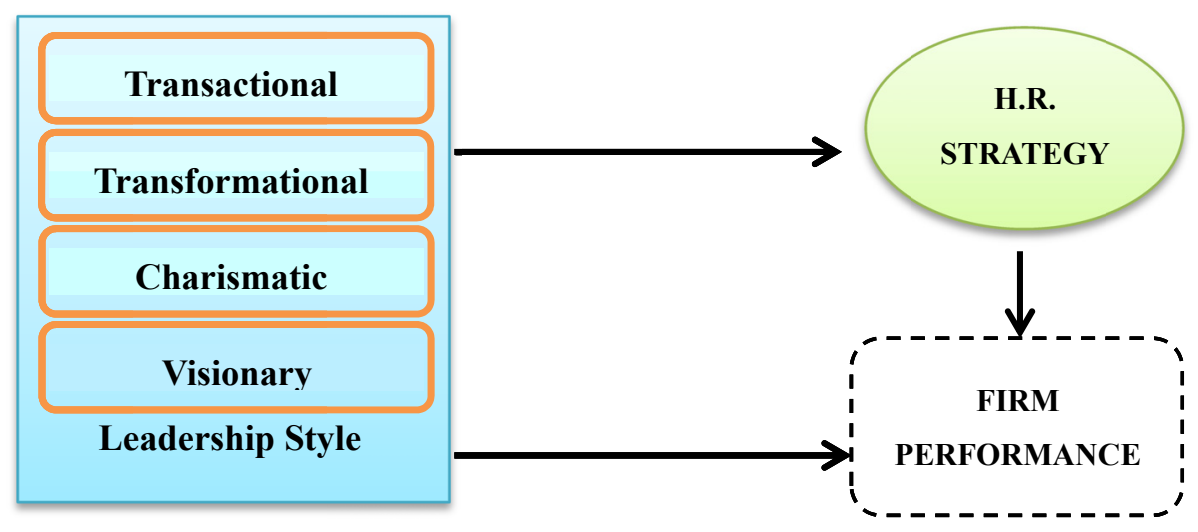

Figure 1. Research model

\subsection{Data Collection}

The present study used a quantitative method with a self-administrated questionnaire distributed based on a convenience sample to collect empirical data that measured the three following variables: transformational leadership, firm performance, and strategic HR. Prior to creating the formal questionnaire and analyzing the predictive questionnaire, pilot-tested for the instruments to validate the questionnaire items using SEM-AMOS version 20. CFA was conducted on the structural models and measurement models, direct and indirect impact 
analysis (mediating effect), to test the hypothesized structural model's fit. The questionnaire respondents included enterprise leaders and high-level operations staff from firms operating in various business domains in Saudi Arabia, including consultancies, software firms, banks, insurance firms, airlines, dated manufacturers, and petrochemicals companies.

\subsection{Measuring Instrument}

Because the survey was conducted in Saudi Arabia, the questionnaire had to be translated from English to Arabic and the language on both versions had to be equivalent. Two bilingual (Arabic/English) lecturers from the Al Imam Language Center translated the questionnaire into Arabic, using the double-translation method to ensure that the Arabic version was an accurate representation of the English version (Hair et al., 2006). The questionnaire was pretested and piloted for repeatability and validity using a convenience sample of 18 participants from our target sample. Answers obtained in the pilot test were not included to the study.

\subsubsection{Leadership Style Measurement}

The scale, which was modified from the Zhu et al. (2005) multifactor leadership questionnaire, had 28 questions. Based on frequency performance, leadership behavior was scored on a five-point Likert scale with the following levels: "never", "seldom", "occasionally", “often", and "always". Following the factor analysis, five factors were extracted as shown in Table 1.

\subsubsection{Organizational Performance Measurement}

The questionnaire asked respondents about how their companies had performed over the past three years compared to their competitors. Organizational management performance over the past three years was chosen primarily to reduce short-term variance. The questionnaire had ten items, each of which used Likert's five-point scoring system, with scores ranging from "strongly disagree" to "strongly agree". After the factor analysis, we extracted three factors, as shown in Table 1.

\subsubsection{Human Resource Management Strategy Measurement}

In the present study, the HRM strategy is divided into the following dimensions of the HRM strategy development strategy: transfer strategy, reinforcement strategy, and motivational strategy. This instrument presented by Weng (2002) which developed from different reference based on relevant literature, closed to HRM strategy questionnaire.

\section{Results}

A total of 270 questionnaires were distributed; after eliminating 18 incomplete questionnaires, 251 valid questionnaires remained. The average age of the respondents was 36 years. The job titles of the respondents were chief executive officer, analyst, deputy manager, senior manager, consultant, and management trainee. Work experience ranged from three years to nine. The average leader-follower relationship duration was 3.2 years.

Exploratory factor analysis (EFA) reliability using $\alpha$ value was extracted as shown in Table 1 for all variables.

Table 1. Factor analysis and reliability results

\begin{tabular}{|c|c|c|c|}
\hline Latent variables & Measurement observed items & Factor loading & $\alpha$ \\
\hline \multirow{5}{*}{ Charismatic leadership } & Item 1 & 0.847 & \multirow{5}{*}{0.865} \\
\hline & Item 2 & 0.736 & \\
\hline & Item 3 & 0.698 & \\
\hline & Item 4 & 0.812 & \\
\hline & Item 5 & 0.701 & \\
\hline \multirow{2}{*}{ Transactional leadership } & Item 1 & 0.872 & \multirow{2}{*}{0.921} \\
\hline & Item 2 & 0.903 & \\
\hline \multirow{3}{*}{$\begin{array}{l}\text { Transformational } \\
\text { leadership }\end{array}$} & Item 1 & 0.884 & \multirow{3}{*}{0.828} \\
\hline & Item 2 & 0.811 & \\
\hline & Item 3 & 0.789 & \\
\hline
\end{tabular}




\begin{tabular}{|c|c|c|c|}
\hline \multirow{3}{*}{ Visionary leadership } & Item 1 & 0.779 & \multirow{3}{*}{0.834} \\
\hline & Item 2 & 0.725 & \\
\hline & Item 3 & 0.698 & \\
\hline \multirow{5}{*}{$\begin{array}{l}\text { Organizational } \\
\text { performance }\end{array}$} & Item 1 & 0.801 & \multirow{5}{*}{0.876} \\
\hline & Item 2 & 0.816 & \\
\hline & Item 3 & 0.741 & \\
\hline & Item 4 & 0.722 & \\
\hline & Item 5 & 0.737 & \\
\hline \multirow{6}{*}{$\begin{array}{l}\text { human resource } \\
\text { management strategy }\end{array}$} & Item 1 & 0.832 & \multirow{6}{*}{0.896} \\
\hline & Item 2 & 0.804 & \\
\hline & Item 3 & 0.752 & \\
\hline & Item 4 & 0.688 & \\
\hline & Item 5 & 0.632 & \\
\hline & Item 6 & 0.775 & \\
\hline
\end{tabular}

Table 1 presents the results of the EFA and the Cronbach's alpha. Three major components had eigenvalues $>1$, which cumulatively explains 90.2 percent of the variance. Factor 1 represents "leadership style" and consists of the 13 items that remain from the 17 originally proposed items. Factor loadings $>0.50$ explained 51.7 percent of the variance. Factor 2, "organizational performance", consists of five items with a factor loading $>0.50$ and a percentage of variance of 62.8 percent. The final factor was human resource strategy, which consists of six items out of the nine originally proposed items. In conclusion, the EFA suggests that all of the factors are likely to be constructs of each measure; therefore, the internal consistency of each construct is substantiated.

The data presented in Table 1 provides sufficient evidence of the reliability of the constructs, given that the Cronbach's Alpha is $>0.80$. The next item from the output is the KMO and Bartlett's test (KMO should be $>0.50$ in order for a satisfactory factor analysis to proceed). The KMO measure in Table 1 is 0.940 . The Bartlett's test of sphericity is also significant, at $<0.050$, which indicates that the scales have high levels of internal consistency and are reliable, with Cronbach's Alpha values $>0.921$. This suggests that all of the study's constructs and variables are based on well-established instruments with high reliability scores (from previous studies), and each construct has very good internal consistency.

\subsection{Confirmatory Factor Analysis (CFA)}

Despite the good results produced by EFA, we made modifications using confirmatory factor analysis (CFA) to ensure that our hypothesized model met the SEM assumptions. Although the items were statistically significant under EFA, they may be subject to certain modifications. The measurement model, which is a CFA model, specifies the way in which the variables measured represent a construct that is not measured directly (Hair et al., 2006). We used the AMOS 20.0 software to assess the model and examine discriminant and convergent validity. We used SEM to further analyze the 16 items noted in the CFA. As reported in Table 2, RMSEA and RMR are both well within the ranges of acceptability Abbas et al. (2013) recommended. As noted above, Abbas et al. (2013) indicated that a RMSEA of less than 0.08 indicates both a good fit and a reasonable approximation error within the population. The measurement model's RMR indicates a good fit.

Table 2. Confirmatory factor analysis (CFA)

\begin{tabular}{lllllllll}
\hline CFA Model & df & CMIN & CMIN/df & NFI & GFI & AGFI & CFI & REMSEA \\
\hline Leadership style (Exogenous) & 2 & 2.931 & 1.465 & 0.998 & 0.995 & 0.981 & 0.998 & 0.031 \\
HRM (Exogenous) & 2 & 2.870 & 1.435 & 0.995 & 0.994 & 0.957 & 0.999 & 0.029 \\
$\begin{array}{l}\text { Organizational performance } \\
\text { (Endogenous) }\end{array}$ & 2 & 2.664 & 1.332 & 0.996 & 0.996 & 0.986 & 0.999 & 0.022 \\
\begin{tabular}{l} 
Structural Model \\
\hline
\end{tabular} & 282 & 321.32 & 1.139 & 0.958 & 0.938 & 0.912 & 0.990 & 0.021 \\
\hline
\end{tabular}


Table 3. CMIN (Goodness-of-Fit indices) hypothesized model

\begin{tabular}{lccccc}
\hline Model & NPAR & CMIN & DF & P & CMIN/DF \\
\hline Default model & 66 & 321.32 & 282 & 0.058 & 1.139 \\
Saturated model & 406 & 0.000 & 0 & & 37.457 \\
Structural model & 16 & 14158.805 & 378 & 0.000 & \\
\hline
\end{tabular}

As shown in the tables, all indices indicate that the model has achieved a good level of overall fit.

Table 4. Goodness-of-Fit indices for the research model

\begin{tabular}{lccc}
\hline Measures & & Fit Indices & Threshold Values \\
\hline \multirow{2}{*}{ Absolute Fit Level } & RMSEA & 0.027 & below 0.08 \\
& GFI & 0.927 & 0.90 and Above \\
& P- Value & 0.000 & P- Value $\geq 0.05$ \\
\hline Incremental Fit Level & AGFI & 0.912 & 0.90 and more \\
& CFI & 0.999 & 0.90 and more \\
\hline \multirow{2}{*}{ Parsimonious Fit Level } & TLI & 0.992 & 0.90 and more \\
& NFI & 0.969 & Less than 2.0 \\
\hline
\end{tabular}

\subsection{Hypothesized Model Analysis}

We used AMOS 20.0 Graphics software to run the structural model and test the hypothesized relationship between constructs. We compared the structure coefficients between latent variables using the maximum likelihood (ML) estimation to. We examined the goodness-of-fit indices (GOF) ML having assumed normal distribution among the observed variables. The model hypothesized in Figure 1 yields a $\chi^{2}$ (chi-square) of 321.32 , a degree of freedom of 282 , and a $P$-value of 0.000 (which is not significant at the 0.050 level); this indicates that, apart from the $P$-value, the model fits the data very well. However, the chi-square statistic is especially sensitive to the sample size, which means it is more appropriate to consider other fit measures. All of the other fit measures indicate the model's goodness of fit to the data, based on Table 3 .

\subsection{Mediating Effect of the Hypothesized Model}

When a third variable or construct intervenes between two related constructs, this creates a mediating effect (see Table 5). The mediating effects of HR strategy were tested in the relationship between perceived leadership style and organizational performance. The results indicate that HR strategy is a partial mediator and its significant indirect effect of 0.381 does support the model we hypothesized in $\mathrm{H} 3$.

Table 5. Total effects of mediator in the research model

\begin{tabular}{cccc}
\hline & \multicolumn{2}{c}{ Endogenous Variable (Organizational performance) } & Total effect \\
\hline Leadership style & Indirect effect & Direct effect & $0.432^{* *}$ \\
\hline
\end{tabular}

\subsection{Hypothesis Testing of the Research Model}

Abbas et al. (2013) showed that each parameter's un- standardized estimate (SE) has regressions weights present, where the estimation of the critical ratio (CR.) is divided into the SE. 
Table 6. Regression weight for testing the hypotheses results

\begin{tabular}{cccccc}
\hline H. & Estimate & SE. & C.R. & P & Hypothesis Support \\
\hline H1 & 0.818 & 0.053 & 11.396 & ${ }^{* * *}$ & Asserted \\
H2 & 0.258 & 0.030 & 8.667 & ${ }^{* * *}$ & Asserted \\
\hline
\end{tabular}

\section{Discussion}

This study has examined how leadership style, HRM strategy, and organizational performance are related, and has also inquired as to whether the relationship between HRM strategy and leadership style affects organizational performance. Based on our findings, an organization wishing to promote organizational performance can start to adjust its leadership style. This finding is consistent with Guardia (2007) who state that transactional leadership to be the primary factor behind organizational success at the team and individual levels, leadership is considered an active way to develop management and improve organizational performance (Voon \& Ayob, 2011), effective leadership behaviors can help improve performance when organizations are faced with such new challenges (Ali et al., 2013), leadership is a key driving force behind the management performance of any organization (Zhu et al., 2005).

In this study, HRM strategy had a significantly positive (partially mediated) the relationship between leadership style and organizational performance. This finding is consistent with Roslan et al. (2013) showed that strategic human resource is a major key can positively effect and improve organization performance. According Riaz and Haider (2010), innovative HRM strategies; such as training; careful selection; and incentive compensation, correlates positively with organizational performance. Overall, an enterprise will be affected by its development, motivational strategy, reinforcement, and transfer strategies (Glenn, 2013; Riaz \& Haider, 2010); all of these strategies will directly affect the enterprise's organizational performance. In HRM strategies, the effect of the first two strategies on organizational performance is significantly positive. In other words, an organization's performance will receive a significant boost if it uses either the motivational strategy or the development strategy for management. This suggests that implementing development and motivational strategies for employees with high work willingness, and for employees with low work willingness but high work ability, will help promote organizational performance.

\section{Conclusion}

It can be concluded that leadership styles of SMEs owners/managers can influence the success and survival in various business domains in Saudi Arabia, including consultancies, software firms, banks, insurance firms, airlines, dried dated manufacturers, and petrochemicals companies. Different leadership styles may affect performance. The present study has used HRM strategies to establish a model with which to analyze the relevance between organizational performance and various leadership styles. This can be used as a reference basis for future related research. The various leadership styles here can serve as a basis with which enterprises can implement various HRM strategies. An enterprise can use this information to promote recognition and devotion among its employees based on a range of strategies, and then creates overall performance of the organization. Also, it is possible to use different leadership styles for different strategies. Consequently, this study has both theoretical and practical reference value. The results should have value for enterprises looking for suitable leadership candidates when implementing their HRM strategy.

\section{Research Implications}

Although some researchers Glenn (2013); Riaz and Haider (2010) have suggested a hypothesized leadership-performance relationship, the existing findings are inconclusive and hard to interpret. Scholars such as Roslan et al. (2013) and Ali et al. (2013) are split regarding whether leadership helps enhance organizational performance. The various concepts of leadership used by these studies have made direct comparisons virtually impossible. The failure to distinguish levels of leadership has left gaps and unanswered questions in the literature. There is, consequently, a need for future research to re-test the proposed leadership-performance relationship.

\section{References}

Abbas, N. A. (2013). Applying a SERVQUAL Model to Measure the Impact of Service Quality on Customer Loyalty among Local Saudi Banks in Riyadh. American Journal of Industrial and Business Management, 3(8), 700-707. http:// dx.doi.org/10.4236/ajibm.2013.38079

Abbas, N. A, Suleiman, A., \& Almualla, A. (2013). Using structural equation modeling for beginner. Jordan, 
Amman: Ithraa, Inc.

Ali, A. S., Sidow, M. A., \& Guleid, H. S. (2013). Leadership styles and job satisfaction: empirical evidence from Mogadishu universities. European Journal of Management Sciences and Economics, 1(1), 1-10.

Bass, B. M. (1997). Transformational leadership: Industrial, military, and educational impact. Mahwah, NJ: Lawrence Erlbaum Associates.

Behling, O., \& Mcfillen, J. (1996). A Syncretical Model Charismatic or Transformational Leadership. Group and Organization Management, 21(2), 120-160. http://dx.doi.org/10.1177/1059601104273061

Boehnke, K., Bontis, N., Distefano, J., \& Distefano, A. (2003). Transformational Leadership: An Examination of Cross-national Differences and Similarities. Leadership and Organization Development Journal, 24(1), 5-17. http://dx.doi.org/10.1108/01437730310457285

Burns, J. M. (1978). Leadership. New York, NY: Harper \& Row.

Choi, F. D., \& Mueller, S. (1992). What is Coefficient Alpha? An Examination of Theory and Application. J. Appl. Psychol. 78(2), 98-104.

Dyer, L., \& Holder, G. (1988). Toward a strategic perspective of human resource management. In L. Dyer (Ed.), Human Resource Management: Evolving Roles and Responsibilities, ASPA BNA Handbook of Human Resource Management. Washington: Bureau of National Affairs.

Feinberg, J. B., Ostroff, C., \& Burke, W. W. (2005). The role of within group agreement in understanding transformational leadership. Journal of Occupational and Organizational Psychology, 78(3), 471-489. http://dx.doi.org/10.1348/096317905X26156

Fiedler, P. (1969). A Theory of Leadership Effectiveness. New York: McGraw-Hill.

Fry, L. (2003). Towards a Theory of Spiritual Leadership. The Leadership Quarterly, 14, $693-727$. http://dx.doi.org/10.1016/j.leaqua.2003.09.001

Gillespie, N., \& Mann, L. (2004). Transformational leadership \& shared values: the building blocks of trust. Journal of Managerial Psychology, 19(6), 588-607. http://dx.doi.org/10.1108/02683940410551507.

Glenn, G. (2013). Strategic Human Resource Management: Influences on Perceived Organizational Support and Job Attitudes. International Journal of Business and Social Science, 4(12), 6-15.

Guardia, A. B. (2007). Leadership, group effectiveness, and group performance: An assessment of a theoretical systems model and an observed structural equation. Proquest Information and Learning Company.

Guo, L. Z. (2004). Strategic leadership has effect on organizational performance: The learning organization as an intermediary variable. Unpublished doctoral dissertation, National Taipei University, Taipei, Taiwan.

Hair, J., Black, W., Babin, B., Anderson, R., \& Tatham, R. (2006). Multivariate data analysis (6th ed.). New Jersey: Upper Saddle River, Pearson Education, Inc.

Hewson, R. (1997). New Dimensions in Strategic Leadership. Strategy Leadership Journal, $25(5), 42-47$. http://dx.doi.org/10.1108/eb054600

House, R. J., \& Aditya, R. N. (1997). The Social Scientific Study of Leadership: Quo Vadis. Journal of Management, 23(3), 409-473.

Judge, T. A., \& Piccolo, R. F. (2004). Transformational \& Transactional Leadership: A Meta-Analytic Test of Their Relative Validity. Journal of Applied Psychology, 89(5), 755-768. http://dx.doi.org/10.1037/0021-9010.89.5.755

Keller, T. (1992). Transformational leadership and performance of research and development project groups. Journal of Management, 18, 489-501. http://dx.doi.org/10.1177/014920639201800304

Lado, A., Boyd, N., \& Wright, P. (1992). A Competency-based Model of Sustainable Competitive Advantage: Toward a Conceptual Integration. Journal of Management, 18(1), $77-91$. http://dx.doi.org/10.1177/096977640200900303

Long, C. S., \& Thean, L. Y. (2011). Relationship between leadership styles, Job satisfaction and employees' Turnover intention: A literature review. Research journal of business management, 5(3), 91-100. http://dx.doi.org/10.3923/rjbm.2011.91.100

McGrath, G. R., \& MacMillan, I. C. (2000). Entrepreneurial Mindset: Strategies for Continuously Creating Opportunity in an Age of Uncertainty. Harvard Business School Press Books. 
McShane, S. L., \& VonGlinow, M. A. (2000). Organizational Behavior. Burr Ridge, IL: Irwin/McGraw-Hill.

Mehra, A., Smith, B., Dixon, A., \& Robertson, B. (2006). Distributed Leadership in Teams: The Network of Leadership Perceptions and Team Performance. Leadership Quarterly, 17, 232-245. http://dx.doi.org/10.1016/j.leaqua.2006.02.003

Mousavi, S. H., Heidary, A., \& Pour, F. K. (2011). The relationship between leadership styles and physical education teachers' creativity. International Journal of Academic Research in Business and Social Sciences, 1(3), 82-84. http://dx.doi.org/10.6007/ijarbss.v1i2.19

Nijssen, S., \& Douglas, P. (2004). Examining the animosity model in a country with a high level of foreign trade. International Journal of Research in Marketing, 21(2), 23-38. http://dx.doi.org/10.1016/j.jiresmar.2003.05.001

Northouse, P. G. (2011). Introduction to leadership: Concept and practice. Thousand Oaks: Sage Publications, Inc.

Purcell, J., Kinnie, N., Hutchinson, S., Rayton, B., \& Swart, J. (2004). Understanding the People \& Performance Link: Unlocking the Black Box. Research Report, Chartered Institute of Personnel and Development.

Qin, M. C. (1998). Educational Administration. Theory Part. Taipei: Wu-Nan.

Riaz, A., \& Haider, M. H. (2010). Role of Transformational and Transactional leadership on jobsatisfaction and Career satosfaction. Business Economic Horizontal, 1(1), 29-38.

Robbins, S. P. (2003). Organizational behavior. Upper Saddle River, NJ: Prentice Hall.

Roslan, A. A., Abdullah, M. H., Tajudin, A., \& Mahmood, R. (2013). The effect of leadership styles on the business performance of SMEs in Malaysia. International Journal of Economics Business and Management Studies, 2(2), 45-52.

Rowe, W. G. (2001). Creating Wealth in Organizations: The Role of Strategic Leadership. Academy of Management Executive, 15, 81-94. http://dx.doi.org/10.5465/AME.2001.4251395

Schuler, R. S. (1989). Strategic human resource management and industrial relations. Human Relation Journal, 42(2), 157-184. http://dx.doi.org/10.1177/001872678904200204

Stodgily, F. (1990). Handbook of Leadership: Theory. Research and Managerial Applications. New York: Free Press. J. Psychol., 25, 35-71.

Tarabishy, A., Solomon, G., Fernald, W., \& Sashkin, M. (2005). The Entrepreneurial Leaders Impact on the Organizations Performance in Dynamic Markets. Journal of Private Equity, 8(4), 20-29. http://dx.doi.org/10.3905/jpe.2005.580519

Teece, D. J., Pisano, G., \& Shuen, A. (1997). Dynamic Capabilities \& Strategic Management. Strategic Management Journal, 18(7), 509-533. http://dx.doi.org/10.1002/(SICI)1097-0266(199708)18:7<509::AID-SMJ882>3.

Voon, M. L., \& Ayob, M. C. (2011). The influence of leadership styles on employees' job satisfaction in public sector organization in Malaysia. International Journal of Business, Management \& Social Sciences, 2(1), $24-32$.

Weng, R. T. (2002). A study on cross-cultural and human resource management strategy of Taiwan affiliates in Mainland China. Unpublished master's thesis, I-Shou University, Kaohsiung, Taiwan.

Zhu, W., Chew, K. H., \& Spangler, W. D. (2005). CEO transformational leadership and organizational outcomes: the mediating role of human capital enhancing human resource management. The Leadership Quarterly, 19, 39-52. http://dx.doi.org/10.1016/j.leaqua.2004.06.001

\section{Copyrights}

Copyright for this article is retained by the author(s), with first publication rights granted to the journal.

This is an open-access article distributed under the terms and conditions of the Creative Commons Attribution license (http://creativecommons.org/licenses/by/3.0/). 